\title{
Examining of the Relationship Between Pilot's Leadership Styles and Crew Resource Management Practices (CRM) in Airline Operations
}

\author{
Ezgi Berte KUTLU1
}

${ }^{1}$ Research Assistant, Istanbul Aydin Unversity, Avration Management (Ing) Department, ezgibkutlu@,aydin.edu.tr

\section{Mahmut Melih BAŞDEMİR²}

${ }^{2}$ Captain Pılot Dr., Turkish Arrlines, metat3000@,hotmail.com

DOI: $10.52995 /$ jass.1034004

ORCID: 0000-0001-5811-2118, 0000-0001-8380-2700

\begin{abstract}
This study was carried out for the purpose to research the relationship between pilot's leadership styles and crew resource management practices. The data obtained were collected from 104 pilots working at the airports in Istanbul by survey data collection method; 3 of them were deemed invalid and 101 questionnaires were tested in the SPSS'21 package program. Factor analysis was executed to test the validity and reliability of the scales and as a result of the normality analysis applied, spearmen correlation analysis was applied based on the assumption that the distribution was not normal; linear regression analysis was applied to test the effect hypothesis. As consequence of the regression analysis, it has been revealed that has a meaningful and positive effect on attitudes towards the cockpit management of the pilot's autocratic leadership style; on attitudes towards individual performance in stress, fatigue and emergency situations of democratic leadership style; on attitudes towards communication, coordination and teamwork of libertarian leadership style. It is thought that the study will contribute to the understanding of the "leadership approaches of pilots" in crew resource management practices and thus contribute to flight safety.
\end{abstract}

Keywords: Leadership, Leadership Style, Crew Resource Management, Flight Safety 


\title{
Havayolu Operasyonlarında Pilotların Liderlik Tarzları ve Ekip Kaynak Yönetimi (EKY) Uygulamaları Arasındaki İlişkinin İncelenmesi
}

\begin{abstract}
ÖZET
Bu çalışma, pilotların liderlik tarzları ve ekip kaynak yönetimi uygulamaları arasındaki ilişkinin incelenmesi amacıyla gerçekleştirilmiştir. Elde edilen veriler, İstanbul'daki havalimanlarında çalışan 104 pilottan anket veri toplama yöntemiyle toplanmış; 3 tanesi geçersiz sayılmış olup 101 adet anket formu SPSS’21 paket programında test edilmiştir. Ölçeklerin güvenirlilik ve geçerliliğini test etmek için faktör analizi yapılmış ve uygulanan Normallik Analizi sonucunda dağılımın normal olmadığı varsayımına dayanarak spearmen korelasyon analizi uygulanmış olup; etki hipotezlerini test etmek için doğrusal regresyon analizi kullanılmıştır. Yapılan regresyon analizi sonucunda, pilotların otokratik liderlik tarzının kokpit yönetimine ilişkin tutumlar üzerinde; demokratik liderlik tarzının stres, yorgunluk ve acil durumlarda bireysel performansa ilişkin tutumlar üzerinde; liberal (serbesiyetçi) liderlik tarzının iletişim, koordinasyon ve ekip çalışmasına ilişkin tutumlar üzerinde anlamlı ve pozitif yönde bir etkisinin olduğu ortaya konmuştur. Bu doğrultuda, çalışmanın ekip kaynak yönetimi uygulamalarında "pilotların liderlik yaklaşımlarının" anlaşılmasına katkıda bulunacağı ve böylelikle uçuş emniyetine katkı sağlayacağı düşünülmektedir.
\end{abstract}

Anahtar Kelimeler: Liderlik, Liderlik Tarzı, Ekip Kaynak Yönetimi, Uçuş Emniyeti

\section{INTRODUCTION}

Leadership, by its nature, is one of the subjects that aviation is most interested in (Bass, 1990: 3). Given the complex nature of leadership, there is no single familiar accepted definition of leadership. The word leader was brought to the literature by the english writer Samue Johnson in 1755; The word meaning is expressed as commander, leading person and captain (Antonakis et al., 2004: 3). Considering that the concepts of leader and leadership are different from each other, leadership; it is possible to define it as the ability to bring individuals together around organizational goals and to act in line with these goals (Güney, 2015: 336).

As in every field, it is also known that leadership and managerial attitudes affect employee performance in the aviation industry. At this point, crew resource management practices carried out important in order to increase the efficiency of flight crews, to realize the importance of the human factor in aviation and to reduce possible errors. Crew resource management practices are critical to improved operational performance; it focuses on "non- 
Examining of the Relationship Between Pilot's Leadership Styles and Crew Resource Management Practices (CRM) in Airline Operations

technical abilities" as leadership, situational awareness, decision making, teamwork and communication (Flin et al., 2002: 68).

In addition to the individual's social and cognitive abilities and experiences; it is known that crew resource management develops within the framework of issues included in the organizational climate, such as strong team performance, trainings that support behavior, measures against possible accidents and problems. The key element in this cyclical process is safe operational performance. Pilots in the "leader" profile in crew resource management practices play a critical role in determining and supporting operational team performance.

Within the framework of this information, this the study focuses on the concepts of leadership and crew resource management and the traditional leadership behaviors known as autocratic, democratic and liberal leadership styles; 1ts relationship with attitudes towards crew resource management such as communication and coordination, stress and emergency management, and cockpit management has been examined. Through the data obtained from the pilot participants, considering the assumption that the distribution is not normal, it was applied "spearmen correlation analysis" to evaluate the relationship between the variables and "linear regression analysis" to test the effect hypothesis.

\section{CONCEPTUAL FRAMEWORK}

\subsection{Leadership Concept}

The leadership process in which the leader is involved turns into a social impact process with the attendance of the subordinates in the endeavour to reach the organizational aims. A leader is someone who empowers or effects others to succeed certain aims; also leadership can explain as the skill to mobilize individuals for these purposes (Nanjundeswaraswamy \& Swamy, 2014: 57). It is known that leadership characteristics are effective on social cohesion, constructive behavior and internal motivation (Birol \& Yazıc1, 2011: 115). At this point, if the tasks within an organization are highly configured and the leader has good relations with his employees, the level of effectiveness for the employees will be expected to be high.

\subsubsection{Leadership styles}

Leadership style is known as the total of characteristic and abilities that leaders use when interacting with his subaltern (Ojokuku et al., 2012: 202). Leadership has become one of the issues that can cause many accidents, have an impact and isolate in the aviation industry. Considering that leadership is in a constant relationship with flight safety and risk management issues, the effect of leadership behavior applied by pilots on flight safety is 
Examining of the Relationship Between Pilot's Leadership Styles and Crew Resource Management Practices (CRM) in Airline Operations

inevitable. The fact that flight safety is possible with a successful flight crew represents the integrated process of technology and human factor. Therefore, responsible captain pilot's in flight operations need to establish a systematic, rigorous and comprehensive environment of trust at the point of decision-making and prioritize the communication factor (Ayiei et al. 2020: 2). With the separation of leadership styles as traditional and modern in the literature, this study will be carried out within the framework of autocratic, democratic and libertarian leadership behaviors, which are among the traditional leadership styles.

\subsubsection{Autocratic leadership}

Autocratic leadership style arises because the leader has absolute power in a group or organization. The leader, as the person who takes the responsibility for the execution and conclusion of the work alone, expects his colleagues to follow his instructions and implement the decisions that he took (Wang, Liu \& Liu, 2019: 2). Autocratic leadership represent centralization of control in teams. This situation have both positive and negative effects on team climate and team performance. Autocratic leadership can limit the control of subordinates on decisions and hence team members can feel worthless. Conversely, when the admissibility of autocratic leadership is considered to be related to the organizational culture in which leadership is practiced, leaders can benefit from the psychological safety of the team and thus team performance. At this point, it is also known that autocratic leaders support team members by providing direction and clarity (Hoogh, Greer \& Hartog, 2015: 3).

\subsubsection{Democratic leadership}

Democratic leadership, also known as participant leadership; it is a leadership style in which employees are further active in the decision-making process. In a democratic structure, the decision-making process is not centricalization; for this reason, it is known that there is the potential to make wrong decisions depending on the additive made by the subaltern (Jony, Alam, Amin \& Alam, 2019: 30). Even though, a democratic leader will make the final decision; he include all the team members to the decision-making process. This not only increases job satisfaction by including team members in what is happening; but also provide to improve their abilities. Because of feedback takes time, this leadership approach results in slower development of events, but generally the conclusion is better. Democratic leadership style is preferred more when teamwork is required and productivity is more important than speed (Gastil, 1994: 955). 
Examining of the Relationship Between Pilot's Leadership Styles and Crew Resource Management Practices (CRM) in Airline Operations

Ezgi Berte KUTLU- Mahmut Melih BAŞDEMIR

\subsubsection{Libertarian Leadership}

Libertarian leadership is also known as a "hands-on" style of behavior. It refers to a situation where the leader gives little or no direction, giving employees as much freedom as possible. All authority within the organization is given to employees; goals are set and finalized by them. The most distinctive feature of the libertarian leadership style is independence and capability. It is an effective style that can be used when employees are highly skilled, experienced and trained (Sharma \& Singh, 2013: 55). Leaders who adopt a libertarian leadership style have little control over their subordinates and allow their subordinates the freedom to actualize assigned tasks without direct control. While this attitude gives his subordinates the authority to make decisions; it is also an indication that they have agreed to abide by the decisions that they have taken (Tarsik, Kassim \& Nasharudin, 2014: 3).

The pilots are the leaders who plan the missions and make the final decision during the flight; it is known that they have the authority to assign flight crews to new duties in case of emergency during normal flight operations, while carrying out the common duties included in the SOP (standard operation procedures). In order to achieve this, communication between the captain who the natural leader and the flight crew is important. Almost all of the leadership types mentioned above have certain authority dynamics (Ginnet, 1993: 74). Although the leadership behavior of the captain pilot changes as one of the 3 leadership styles mentioned above, especially in normal situations, the captain makes the final decision; The responsibility rests with the captain pilot. Studies show that autocratic leadership is effective during an emergency (Yun, Faraj \& Sims, 2007: 1288). Basically, it is thought that the effective leadership behavior exhibited by the captains in flight operations is to establish a balance between democratic and autocratic leadership. Standardized commands in aviation language significantly affect the way of team communication. It is thought that cockpit leaders should influence members through less direct commands and behaviors suggesting consideration of expected behavior using the directive type of communication.

\subsection{Crew Resource Management Concept}

Crew resource management designed to perform safe flight operations and reduce human errors, can be express as the best use of all available resources (knowledge, material and labor) by an air crew. Pilots who use high-tech machines and whose main responsibility is to ensure flight safety, sometimes conflict with their colleagues and the system they are in; these conflicts result in undesired errors. In order for the responsibilities given to the pilots to address the purpose, the cabin crew must successfully perform their roles (Laukkala et al., 
Examining of the Relationship Between Pilot's Leadership Styles and Crew Resource Management Practices (CRM) in Airline Operations

2018: 95). Crew resource management practices cover a series of attitudes and strategies that the flight crew has and should follow in the name of safety; clearly emphasizes the importance of the human factor in the aviation industry.

\subsubsection{Attitudes towards crew resource management}

In aviation, "non-technical abilities" are as important as flight behavior regarding technical knowledge and skills for pilots and cabin crew. In addition to the cognitive and social talents necessary for safe and secure flight operations, there are also human factors that can affect these skills. As it is known that pilot's attitudes towards crew resource management affect the quality and success of crew resource management practices, it is clear that technical skills alone will not be sufficient to carry out a flight operation (Flin \& Maran, 2015: 31). In this regard, the relevant study is aimed at pilot's crew resource management applications; such as communication, coordination and teamwork, cockpit management, stress and fatigue will be examined within the framework of attitudes related to individual performance.

\subsubsection{Attitudes towards communication, coordination and teamwork}

In aviation, it is known that effective communication between cabin crew and pilot is a supportive element in coordinating tasks and being prepared for possible risks. In this respect, it can be said that communication plays an intermediary role in achieving the goals set for safe and effective flight operations.

The concept of communication between the flight crew is an important element of the concept of coordination. In the reports filed about flight 173 of United Airlines in 1978, it was stated that the main cause of the accident was fuel depletion, in addition to the lack of communication between the captain and cabin crew (NTSB, 1978: 18). Several of studies have provided results confirming the inadequacy of flight crew coordination at critical moments. It is seen that the main reason for the accidents is the inadequacy of information exchange in the cockpit and the inability to communicate (Aktaş \& Tekarslan, 2013: 281). It is a fact that the success of the communication between the flight crew contributes to the coordination and teamwork. At this point, it is thought that pilots should exhibit leadership behavior in a way that raises awareness of the element of inter-team communication.

\subsubsection{Attitudes towards cockpit management}

Crew resource management practices that express the efficient use of all sources in the cockpit and during flight operations to ensure safe and effective flight operations; flight safety improvement efforts, selection of flight personnel, special training in resource 
Examining of the Relationship Between Pilot's Leadership Styles and Crew Resource Management Practices (CRM) in Airline Operations

management focused on the flight crew interplay process and its relationship with flight performance (Gregorich, Helmreich \& Wilhelm, 1990: 684). As it is known that authority is an important element in leadership; If the captain's authority is high, the 2nd pilot's power to observe and control the flight actions of the captain may decrease. If the authority is low, it may cause that the captain pilot does not fulfill his duty to control the 2nd pilot. In both cases, errors related to cockpit management bring along various risks and accidents. Therefore, the leadership behaviors of both the captain and the 2nd Pilots have a direct effect on the crew resource management practices. It is known that behavioral problems and distuptions experienced in cockpit management cause problems that may arise not to be managed.

\subsubsection{Attitudes towards individual performance in stress, fatigue and emergency situations}

Flight operations requires being able to manage complexity, uncertainty, unpredictable situations and unknowns. To reach high levels of safety and performance, it is important for pilots to use adequate cognitive strategies and to ensure stress management (Fornette, et.al., 2012: 210). It is known that flight operations are directly related to the stress level and the reasons under stress. Studies show that stress-interrelated sleep disorder and fatigue may be particularly an important factor (Lowenthal et al., 2000: 179). It is the monotony of the activities performed that mainly influences formation of pilot error in terms of fatigue. The state of getting used to a routine of the human body which is exposed to the same factors for a long time reduces the amount of energy source required for the body to work more. Therefore, pilots unconsciously fall into the monotony characterized by other causes, but experience symptoms similar to exhaustion. There are many factors that affect fatigue for pilots (Maciejewska \& Galant-Golebiewska, 2020: 360). These factors are separated to two groups by their nature. The first one includes external factors such as frequent changing of time zones, reduction in pressure inside the aircraft and thus lack of oxygen in the air, noise, vibrations, inactivity and boredom; the latter refers to psycho-physical factors such as stress, confusion, distractibility, sensitivity to caffeine and nicotine, noise, light, physical resistance to certain stimuli, which are described as individual characteristics (Luczak \& Zuzewicz, 2006: 22). At this point, it is clear that internal and external factors are triggers of stress and exhaustion. 
Examining of the Relationship Between Pilot's Leadership Styles and Crew Resource Management Practices (CRM) in Airline Operations

Ezgi Berte KUTLU- Mahmut Melih BAŞDEMIR

\section{RESEARCH METHOD}

\subsection{Purpose of Research}

The purpose of this research is to reveal the relation between the leadership styles of pilots and their crew resource management practices. Determining the relation between pilot's practices regarding crew resource management attitudes and leadership behaviors is a condition for flight safety; in addition to important for the research topic.

\subsection{Research Universe and Sample}

The universe of the research consists of 412 pilots working in airline companies of Turkish origin in Istanbul, and company naming rights are kept confidential due to operating policies. The pilots constituting the main body were informed about the research via e-mail and various written channels; 104 pilots participated voluntarily and formed the sample of the study. 3 questionnaires with missing data were deemed invalid and 101 participant data were analyzed.

\subsection{Research Question and Hypothesis}

The research question expressed based on the relation between leadership and crew resource management was determined as follows: among 3 important dimensions representing crew resource management practices (attitudes towards communication, coordination and teamwork; attitudes towards cockpit management; attitudes towards stress, fatigue and individual performance in emergency situations) and 3 important dimensions representing the leadership styles of pilots (autocratic leadership, democratic leadership, libertarian leadership), 1s there a statistically significant relation?

$\mathrm{H}_{1 .:}$ There is a meaningful relation between pilot's autocratic leadership styles and cockpit management attitudes.

$\mathrm{H}_{2:}$ There is a meaningful relation between pilot's autocratic leadership styles and their attitudes towards communication, coordination and teamwork.

$\mathrm{H}_{3 .:}$ There is a meaningful relation between pilot's autocratic leadership styles and their attitudes towards stress, fatigue and individual performance in emergency situations.

$\mathrm{H}_{4 . .}$ There is a meaningful relation between pilot's democratic leadership styles and cockpit management attitudes.

$\mathrm{H}_{5 .:}$ There is a meaningful relation between pilot's democratic leadership styles and their attitudes towards communication, coordination and teamwork. 
Examining of the Relationship Between Pilot's Leadership Styles and Crew Resource Management Practices (CRM) in Airline Operations

$\mathrm{H}_{6:}$ There is a meaningful relation between pilot's democratic leadership styles and their attitudes towards stress, fatigue and individual performance in emergencies.

$\mathrm{H}_{7}$ : There is a meaningful relation between pilot's libertarian leadership styles and cockpit management attitudes.

$\mathrm{H}_{8}$ : There is a meaningful relation between pilot's libertarian leadership styles and their attitudes towards communication, coordination and teamwork.

$\mathrm{H}_{9}$ : There is a meaningful relation between pilot's libertarian leadership styles and their attitudes towards stress, fatigue and individual performance in emergency situations.

$\mathrm{H}_{10:}$ Autocratic leadership style of pilot's has a positive impact on their attitudes towards cockpit management.

$\mathrm{H}_{11}$ : Democratic leadership style of pilot's has a positive impact on their attitudes towards individual performance in stress, fatigue and emergency situations.

$\mathrm{H}_{12 .:}$ Libertarian leadership style of pilot's has a positive impact on their attitudes towards communication, coordination and teamwork.

\subsection{Research Model}

Figure 1: Research Model

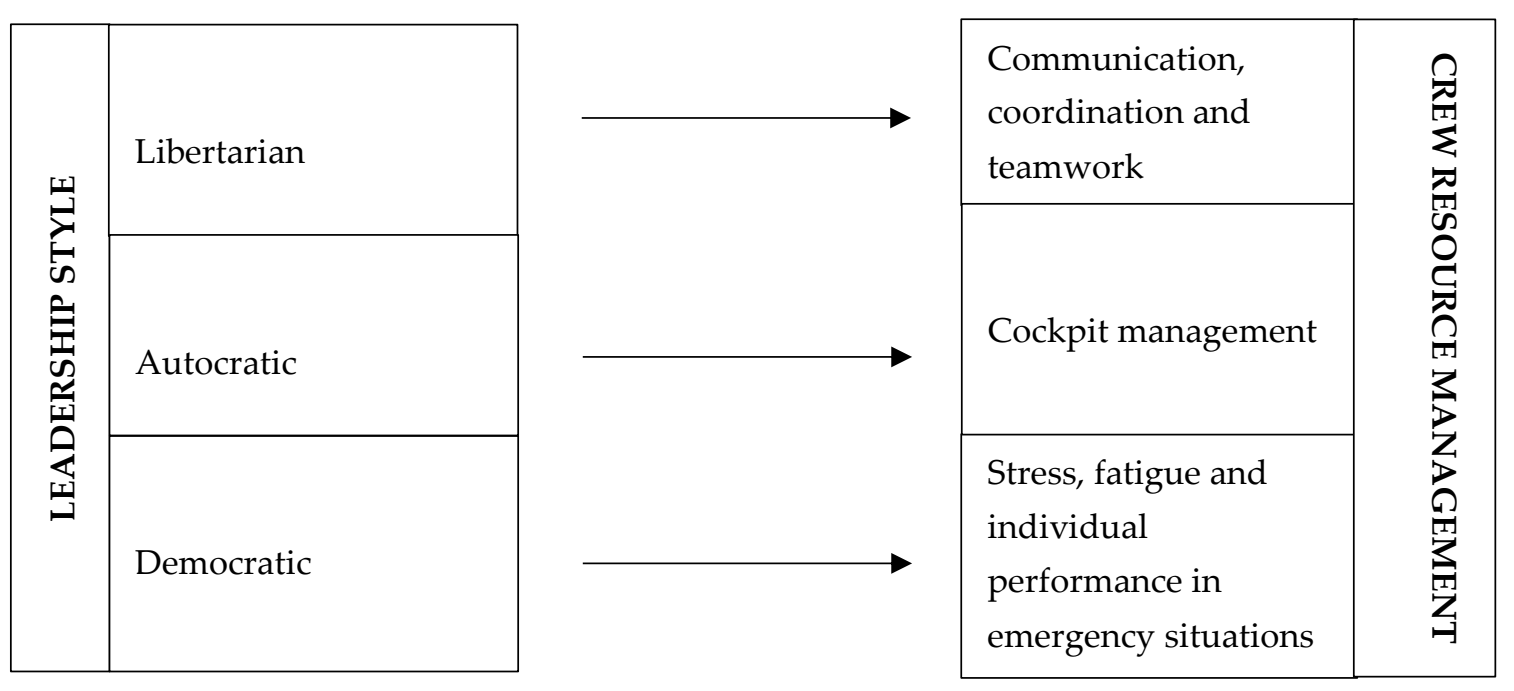


Examining of the Relationship Between Pilot's Leadership Styles and Crew Resource Management Practices (CRM) in Airline Operations

In the research model, the relation between the independent variable of leadership style and the dependent variable of crew resource management attitudes was illustrated by associating them in terms of sub-dimensions.

\subsection{Data Collection Technique}

In the related research, quantitative research techniques were used to examine the relation and differences between variables experimentally. Questionnaire method consisting of 3 parts was used as data collection tool. In the first part of the questionnaire, gender, age, educational background, professional origin and flight experience, which are called personal information; in the second part, 32 statements of the crew resource management attitude scale; in the third part, there are 30 statements belonging to the leadership style scale. The expressions in the "leadership style scale" developed by Clark (2008); it represents 3 dimensions as autocratic leadership, democratic leadership, and libertarian leadership. In the scale, there are 10 statements related to "autocratic leadership" style; 10 statements related to "democratic leadership" style; 10 statements related to "libertarian leadership" style. The statements in the "flight crew resource management attitude scale" developed by helmreich et al. (1988), helmreich et al. (1993) and (merritt, 1996); " as "attitudes towards communication, coordination and teamwork", "attitudes towards cockpit management", " attitudes towards individual performance in stress, fatigue and emergencies" represents 3 dimensions. There are statements that " 10 related to communication, coordination and teamwork attitudes; " 14 related to cockpit management attitudes"; 8 related to "individual performance in stress, fatigue and emergency situations attitudes" on the scale. The expressions in the scales were directed to the participants utilizing a 5-point likert style scale with 5 options: "I strongly agree", "1 agree", "1 indecisive ", "1 do not agree", "1 strongly disagree". Factor analysis was executed to measure the structural validity of the scales used; as a result of the analysis, some expressions in the "crew resource management attitude scale" were removed from the scale because they carry a negative factor load. On the contrary, the "leadership style scale" was used in the same way as there was no statement with a negative factor load.

Personal information in the questionnaire, leadership style inventory and resource management team descriptive statistics and hypothesis testing of the expression of the scale were analyzed by software package SPSS'21. According to the kolmogorov-smirnov test statistic which was taken into account depending on the number of samples in the normality analysis applied, $\mathrm{p}<0.05$ was found for all sub-dimensions of the scales and it was assumed 
Examining of the Relationship Between Pilot's Leadership Styles and Crew Resource Management Practices (CRM) in Airline Operations

that the distribution was not normal. Under this assumption, it was applied "spearmen correlation analysis" for the purpose of test the relation between variables and "linear regression analysis" to test effect of this relation. The margin of error in all analyzes was accepted as 0.05 .

\section{FINDINGS}

\subsection{Demographic Findings}

Table 1: Frequency Analysis

\begin{tabular}{|c|c|c|c|}
\hline \multicolumn{2}{|c|}{ VARIABLES } & \multirow{2}{*}{$\frac{\mathbf{N}}{2}$} & \multirow{2}{*}{$\begin{array}{r}\mathbf{\%} \\
2\end{array}$} \\
\hline Gender & Woman & & \\
\hline & Man & 99 & 98 \\
\hline \multirow[t]{4}{*}{ Age } & $25-30$ & 4 & 4 \\
\hline & $30-35$ & 14 & 13,9 \\
\hline & $35-40$ & 6 & 5,9 \\
\hline & 40 and over & 77 & 76,2 \\
\hline \multirow[t]{4}{*}{ Educational Status } & Associate degree & 3 & 3 \\
\hline & Bachelor degree & 59 & 58,4 \\
\hline & Master degree & 36 & 35,6 \\
\hline & Doctorate & 3 & 3 \\
\hline \multirow[t]{2}{*}{ Vocational Origin } & Military origin & 69 & 68,3 \\
\hline & Civilian origin & 32 & 31,7 \\
\hline \multirow[t]{4}{*}{ Flight Experience } & $1-5$ years & 17 & 16,8 \\
\hline & $5-10$ years & 7 & 6,9 \\
\hline & $10-15$ years & 2 & 2 \\
\hline & 15 years and over & 75 & 74,3 \\
\hline
\end{tabular}


Examining of the Relationship Between Pilot's Leadership Styles and Crew Resource Management Practices (CRM) in Airline Operations

When the frequency analysis results given in table 1 are examined; $99 \%$ of the pilot participants were male; It is seen that their age is 40 years and over with a weight of $76.2 \%$. The number of those with undergraduate (58.4\%) and graduate $(35.6 \%)$ education levels is higher. Among the participants, pilots with military vocational origin (69) are more in number. From the point of view of flight experience, it is seen that $74.3 \%$ of the pilots have 15 years or more flight experience.

\subsection{Validity and Reliability Analysis}

Table 2: Reliability Analysis of Leadership Style Scale

\begin{tabular}{ccc}
\hline Scales & $\begin{array}{c}\text { Number of } \\
\text { Expressions }\end{array}$ & $\begin{array}{c}\text { Cronbach's Alpha } \\
\text { Value }\end{array}$ \\
\hline Leadership Style & 30 & 0,823 \\
\hline $\begin{array}{c}\text { Crew Resource } \\
\text { Management }\end{array}$ & 21 & 0,708 \\
\hline
\end{tabular}

Reliability is defined as that measurements made on the same individuals give the same result under similar conditions, that is, consistency, and it is obtained with the coefficient $\alpha$. This method is more about the reliability of common factors than the reliability of group differences, and in this method, the common variance values that maximize the $\alpha$ coefficient for the factors are estimated by the iteration method. In alpha factor analysis, it is aimed to maximize the alpha reliability coefficient (Karaman, 2015: 42). In the light of this information, factor loads that had a negative effect on the alpha coefficient were determined and removed from the scale in this study. As a result of the extracted statements, the reliability coefficients increased. In addition to component factor analysis was implement to measure the construct validity of the scales.

In the factor analysis applied to the leadership style scale developed by Clark (2008), the $\mathrm{KMO}$ value representing the construct validity was found to be $0.711>0.05$ and the value $x^{2}=1182,310$ and herewith the "component factor analysis" which was found to be significant at the $\mathrm{p}=0.000<0.05$ level and no expression carrying negative factor load was found. As a result of the reliability analysis given in table 2, the cronbach's value of the scale is seen to be 0.823 with a confidence level of $82.3 \%$. "Kaiser-meyer-olkin (KMO)" sample sufficiency test and "bartlett's test of sphericity" was applied in order to determine the construct validity of the crew resource management attitude scale by Helmreich et al. $(1988,1993)$ and (Merritt, 
Examining of the Relationship Between Pilot's Leadership Styles and Crew Resource Management Practices (CRM) in Airline Operations

1996) and to test its suitability for confirmatory factor analysis. KMO value was found significant as $0.651>0.05$; value of $\mathrm{X}^{2}=526,873$ and at the $\mathrm{p}=0.000<0.05$ level was confirmed to be suitable for factor analysis. As another consequence of the reliability analysis given in table 2, the cronbach's alpha value was found to be 0.553 ; therefore, after confirming their suitability for factor analysis, 11 expressions $(10,12,14,18,27,29,31,13,19,28,32)$ included in the scale and having negative factor load were removed from the scale with "component factor analysis". According to the analysis results after the scale was reduced to 21 statements, the cronbach's value was increased to 0.708 and the scale was found to be $70.8 \%$ reliable.

4.3. Examining the Scales of Leadership Style and Crew Resource Management

Table 3: Descriptive Statistics towards the Sub-Dimensions of the Leadership Style Scale and Crew Resource Management Attitude Scale

\begin{tabular}{lccccc}
\hline Sub-Dimensions & N & Min & Max & $\begin{array}{c}\text { Arithmetic } \\
\text { Mean }\end{array}$ & $\begin{array}{c}\text { Standard } \\
\text { Deviation }\end{array}$ \\
\hline $\begin{array}{l}\text { Autocratic } \\
\text { Leadership }\end{array}$ & 101 & 2 & 4 & 2,87 & 0,40 \\
\hline $\begin{array}{l}\text { Democratic } \\
\text { Leadership }\end{array}$ & 101 & 1 & 3 & 2,04 & 0,41 \\
\hline $\begin{array}{l}\text { Libertarian } \\
\text { Leadership }\end{array}$ & 101 & 1 & 3 & 2,36 & 0,45 \\
\hline $\begin{array}{l}\text { Communication, } \\
\text { Coordination and } \\
\text { Teamwork }\end{array}$ & 101 & 1 & 3 & 1,80 & 0,43 \\
\hline $\begin{array}{l}\text { Cockpit } \\
\text { Management }\end{array}$ & 101 & 1 & 4 & 2,73 & 0,58 \\
\hline $\begin{array}{l}\text { Stress, Fatigue } \\
\text { and Emergencies }\end{array}$ & 101 & 1 & 4 & 2,09 & 0,67 \\
\hline
\end{tabular}

According to the descriptive statistics results of the leadership style scale in table 3; the standard deviation value of the expressions about the autocratic leadership style showed that some of the participants moved away from the average answer score by 
Examining of the Relationship Between Pilot's Leadership Styles and Crew Resource Management Practices (CRM) in Airline Operations

$40 \%$; the standard deviation value of the expressions related to the democratic leadership style showed that some of the participants moved away from the average response score by $41 \%$; libertarian leadership the standard deviation of the expressions regarding the leadership style shows that $45 \%$ of the average response points out some of the participants. In this case, it is seen that the pilot's level of perception of the expressions given in the leadership style scale is equally acceptable for all three sub-dimensions.

Similarly, according to the descriptive statistics results of the crew resource management attitude scale in table 3; the standard deviation value of the expressions about communication, coordination and teamwork attitudes showed that some of the participants moved away from the average response score by $43 \%$; the standard deviation value of the expressions about cockpit management attitudes showed that some of the participants moved away from the average response score by 58\%; stress, fatigue and emergency expression of the standard deviation about the attitudes shows that $67 \%$ of the average response points out that some of the participants. In this case, the most of expressions perceived by the pilots in the crew resource management attitude scale are; it is seen that there are expressions about the dimensions of communication, coordination and teamwork.

\subsection{Findings towards Research Hypothesis}

4.4.1. Examining the relationship between leadership style and crew resource management attitudes

Table 4: Spearmen Correlation Analysis of Leadership Style and Crew Resource Management Sub-Dimensions

\begin{tabular}{|c|c|c|c|c|}
\hline & & $\begin{array}{c}\text { Autocratic } \\
\text { Leadership }\end{array}$ & $\begin{array}{l}\text { Democratic } \\
\text { Leadership }\end{array}$ & $\begin{array}{l}\text { Libertarian } \\
\text { Leadership }\end{array}$ \\
\hline Cockpit Management & $\begin{array}{l}\mathrm{r} \\
\mathrm{p}\end{array}$ & $\begin{array}{l}0,419 \\
0,000^{* *}\end{array}$ & $\begin{array}{l}0,221 \\
0,026^{*}\end{array}$ & $\begin{array}{l}0,127 \\
0,207\end{array}$ \\
\hline $\begin{array}{l}\text { Communication, } \\
\text { Coordination and } \\
\text { Teamwork }\end{array}$ & $\begin{array}{l}\mathrm{r} \\
\mathrm{p}\end{array}$ & $\begin{array}{l}0,293 \\
0,003^{*}\end{array}$ & $\begin{array}{l}0,513 \\
0,000^{* *}\end{array}$ & $\begin{array}{l}0,465 \\
0,000 * *\end{array}$ \\
\hline $\begin{array}{l}\text { Stress, Fatigue and } \\
\text { Emergencies }\end{array}$ & $\begin{array}{l}\mathrm{r} \\
\mathrm{p}\end{array}$ & $\begin{array}{l}0,201 \\
0,044^{*}\end{array}$ & $\begin{array}{l}0,207 \\
0,038^{*}\end{array}$ & $\begin{array}{l}0,131 \\
0,193\end{array}$ \\
\hline
\end{tabular}


Examining of the Relationship Between Pilot's Leadership Styles and Crew Resource Management Practices (CRM) in Airline Operations

As per the correlation analysis in table 4 , there is a moderately positive $(r=0.419)$ and significant $(\mathrm{p}=0.000<0.05)$ relationship between autocratic leadership style and cockpit management attitudes ( $\mathrm{H}_{1}$ is accepted); a weakly positive $(\mathrm{r}=0.293)$ and significant $(p=0.03<0.05)$ relationship between communication, coordination and teamwork attitudes $\left(\mathrm{H}_{2}\right.$ is accepted $)$; there is a weakly positive $(\mathrm{r}=0.201)$ and significant $(\mathrm{p}=0.044<0.05)$ relationship between stress, fatigue and emergency attitudes $\left(\mathrm{H}_{3}\right.$ is accepted). Likewise, there is a weakly positive $(\mathrm{r}=0.221)$ and significant $(\mathrm{p}=0.026<0.05)$ relationship between democratic leadership style and cockpit management attitudes $\left(\mathrm{H}_{4}\right.$ is accepted); a moderately positive $(\mathrm{r}=0.513)$ and significant $(\mathrm{p}=0.000<0.05)$ relationship between communication, coordination and teamwork attitudes $\left(\mathrm{H}_{5}\right.$ is accepted); there is also a weakly positive $(\mathrm{r}=0.207)$ and significant $(\mathrm{p}=0.038<0.05)$ relationship between stress, fatigue and emergency attitudes $\left(\mathrm{H}_{6}\right.$ is accepted). However, libertarian leadership style was found to have a moderately positive $(\mathrm{r}=0.465)$ and significant $(\mathrm{p}=0.000<0.05)$ relationship with communication, coordination and teamwork attitudes $\left(\mathrm{H}_{8}\right.$ is accepted); it is seen that there is no significant relationship with cockpit management and stress, fatigue and emergency attitudes $\left(\mathrm{H}_{7}\right.$ and $\mathrm{H}_{9}$ is not accepted). According to the analysis findings obtained; there is a moderately relationship between autocratic leadership styles and cockpit management attitudes; a moderately relationship between democratic leadership and stress, fatigue and emergencies attitudes; a moderately relationship between libertarian leadership styles and communication, coordination and teamwork attitudes. For this reason, it was decided to perform a regression analysis between these variables and to include them in the hypotheses in order to determine the effect level between this binary variables that having the highest level of relationship.

\subsubsection{Examining the effect of leadership styles on crew resource management attitudes}

Table 5: Regression Analysis towards Examining the effect of leadership styles Sub-Dimensions on Crew Resource Management Sub-Dimensions

\begin{tabular}{lllll}
\hline Independent & Dependent & $\mathbf{p}$ & $\mathbf{R}^{2}$ & $\mathbf{F}$ \\
\hline Autocratic & Cockpit & $0,000^{* * *}$ & 0,213 & 26,722 \\
Leadership & Management & & & \\
\hline Democratic & Stress, Fatigue, & $0,012^{* *}$ & 0,062 & 6,598 \\
Leadership & Emergency & & & \\
\hline
\end{tabular}


Examining of the Relationship Between Pilot's Leadership Styles and Crew Resource Management Practices (CRM) in Airline Operations

Ezgi Berte KUTLU- Mahmut Melih BAŞDEMIR

Table 5 (devam) : Regression Analysis towards Examining the effect of leadership styles Sub-Dimensions on Crew Resource Management Sub-Dimensions

\begin{tabular}{llll}
\hline Libertarian & Communication, $0,000^{* * *}$ & 0,213 & 26,816 \\
Leadership & Coordination, & & \\
& Teamwork & & \\
&
\end{tabular}

*** $\mathrm{p}<0,01 ; * * \mathrm{p}<0,05$

In Table 5, the impact of autocratic leadership style on the cockpit management dependent variable was tested by regression analysis. Autocratic leadership styles of pilots explain $21.3 \%$ of attitudes towards cockpit management. The beta value shows that the unit increase in the autocratic leadership style increases the attitudes towards cockpit management by $46.1 \%$. The results support positive impact of autocratic leadership style on attitudes towards cockpit management. The regression model is a meaningful at $\mathrm{p}<0,000$. Accordingly, the hypothesis $\mathrm{H}_{10}$ is accepted.

The impact of democratic leadership style on the individual performance in stress, fatigue and emergencies dependent variable was tested by regression analysis. Democratic leadership styles of pilots explain $6.2 \%$ of attitudes towards individual performance in stress, fatigue and emergency situations. The beta value shows that the unit increase in the democratic leadership style increases the attitudes towards individual performance in stress, fatigue and emergency situations by $25 \%$. The results support positive impact of democratic leadership style on attitudes towards individual performance in stress, fatigue and emergencies. The regression model is a meaningful at $\mathrm{p}<0,012$. Accordingly, the hypothesis $\mathrm{H}_{11}$ is accepted.

The impact of libertarian leadership style on communication, coordination and teamwork dependent variable was tested with regression analysis. Libertarian leadership styles of pilots explain $21.3 \%$ of attitudes towards communication, coordination and teamwork. The beta value shows that the unit rise in the libertarian leadership style increases the attitudes towards communication, coordination and teamwork by $46.2 \%$. The results support positive impact of libertarian leadership style on attitudes towards communication, coordination and teamwork. The regression model is a meaningful at $\mathrm{p}<0,000$. Accordingly, the hypothesis $\mathrm{H}_{12}$ is accepted. 
Examining of the Relationship Between Pilot's Leadership Styles and Crew Resource Management Practices (CRM) in Airline Operations

Ezgi Berte KUTLU- Mahmut Melih BAŞDEMIR

\section{CONCLUSION AND DISCUSSION}

Leadership has become an important issue in airline operations as it is in every field. As it is known that flight safety is at the forefront in aviation, it is thought that knowing the quality of the relationship between pilot's crew resource management practices and leadership styles will effect positively to flight safety. This research was realized with aim to measure the relationship between pilot's leadership styles and crew resource management practices and to determine the differences created by socio-demographic variables on this relationship.

Based on the findings obtained as a conclusion of the analyzes, it was seen that there is a moderately relation between the autocratic leadership styles of the pilots and their cockpit management attitudes. On the other hand, there is a weak correlation between pilot's autocratic leadership styles and their attitudes towards communication, coordination and teamwork. This result is thought to support the idea that autocratic leadership behaviors of pilots reduce communication and coordination in flight operations.

While there is a weak relationship between pilot's democratic and libertarian leadership styles and cockpit management attitudes; it has been observed that there is a moderately relationship between attitudes towards communication, coordination and teamwork. At this point, it can be said that autocratic leadership behaviors of pilots are related to crew resource management practices towards cockpit management; democratic and libertarian leadership behaviors of pilots are related to crew resource management practices towards communication, coordination and teamwork.

When the effects on this relationship between the sub-dimensions are examined; it has been revealed that has a significant and positive effect pilot's autocratic leadership style on attitudes towards cockpit management; pilot's democratic leadership style on the attitudes towards individual performance in stress, fatigue and emergencies; pilot's libertarian leadership style on attitudes towards communication, coordination and teamwork. As it is known that autocratic leader undertakes the planning, taking and implementation of decisions on its own, it can be said that this situation is an indication that the positive effect on cockpit management attitudes will result in a faster decision-making and problem-solving process.

It is thought to be the aim of minimizing the conflict environments that the reason for the high relationship between the democratic leadership style with the attitudes towards 
Examining of the Relationship Between Pilot's Leadership Styles and Crew Resource Management Practices (CRM) in Airline Operations

individual performance in stress, fatigue and emergency situations which belong to crew resource management and attitudes towards communication, coordination and teamwork, by moving with opinion to sharing the authority with team members and reaching a common decision. When we examine it in terms of libertarian leadership, it can be argued that the lack of effect on attitudes towards cockpit management and the attitudes towards individual performance in stress, fatigue and emergencies is ineffective on more technical elements, because of the leader in this leadership style delegates all authority to team members and sees himself as no different from team members.

Considering the analysis conclusions, it was appeared that the leadership styles of the pilots have a positive and meaningful effect on the crew resource management practices based on $\mathrm{H}_{10}, \mathrm{H}_{11}, \mathrm{H}_{12}$. Considering that exhibiting effective leadership behaviors during flight operations is important for flight safety, it is clear that crew resource management practices which aim to minimize human errors, are affected by these attitudes.

When past studies are examined, it has been argued that individual's belief in a successful organizational climate and organizational justice perception will keep humaninduced errors at a minimum (Başdemir, 2020: 68). In a study on the relationship between crew resource management and personality, it is argued that personality structures are effective on the behavior of pilots during the operation (Aktaş \& Tekarslan, 2013: 297). In a study conducted in the literature on the leadership behaviors of pilots, taking into account their flight experience, pilots were divided into 3 groups according to their experience level. According to the experience factor of the 2nd pilots, there were meaningful differences between the directives given to the captain pilot and the behavior of reaching the organizational goals. This situation was showed that the experience factor had guiding effect in the reactions of the 2nd pilots to the situations (Prince et al. 2010: 387). In an accident of air india express airlines in 2010 , it was seen that the captain pilot's failure to change the route by ignoring the warnings of the second pilot and thus exhibiting autocratic leadership behavior caused the death of many people. It is thought that realizing the significance of the human factor in aviation and examining the factors on which human behavior is based can prevent air accidents. For this reason, it is known that the leadership behaviors of the pilots who are in the decision-making position have an effect on safety. Since there is no previous study in the field that measures the relation between leadership styles and crew resource management, it is thought that this study is important in terms of determining the relation between pilot's leadership styles and crew resource management practices when socio-demographic characteristics are taken into 
Examining of the Relationship Between Pilot's Leadership Styles and Crew Resource Management Practices (CRM) in Airline Operations

consideration. For future research, it can be said that using the research model developed in the research can contribute to the literature with a larger sample.

\section{REFERENCES}

Ayiei, A., Pollock, L., Khan, F. N., Murray, J., Baxter, G., \& Wild, G. (2020). The Role of Leadership In Aviation Safety And Aircraft Airworthiness. Fatigue of Aircraft Structures, 12, ss.1-14.

Aktaş, H., \& Tekarslan, E. (2013). Uçuş Ekibi Kaynak Yönetimi: Pilotların Uçuş Ekibi Kaynak Yönetimi Tutumları ile Kişilik Yapıları Arasındaki İlişki. İstanbul Üniversitesi İşletme Fakültesi Dergisi, 42(2), ss.276-301.

Antonakis, J., Cianciolo, A. T., \& Sternberg, R. J. (2004). Leadership: Past, Present, Future. In The Nature of Leadership. New York: Sage Publications.

Bass, B. M. (1990). Bass \& Stogdill's handbook of leadership. 3rd edition. New York: The Free Press.

Başdemir, M. M. (2020). Uçuş operasyonlarında insan faktörünün rolü ve pilot performansinı arttıracak öneriler. Journal of Aviation, 4(2), ss.55-70.

Birol Z. N., Yazıc1 H. (2011). Fen ve sosyal bilimler lisesi öğrencilerinde mükemmeliyetçilik, benlik saygisı ve liderlik özellikleri. Karadeniz Uluslararası Bilimsel Dergi, 3 (12), ss.113-122.

Clark, D. R. Leadership Matrix Survey. From http://www.nwlink.com/ donclark/leader/matrix.html (20.11.2009).

Flin, R., O'connor, P., \& Mearns, K. (2002). Crew resource management: improving team work in high reliability industries. Team Performance Management: An International Journal, 8(3/4), ss.68-78.

Flin, R., \& Maran, N. (2015). Basic concepts for crew resource management and non-technical skills. Best Practice \& Research Clinical Anaesthesiology, 29, ss.27-39.

Fornette, M.P., Bardel, M.H., Lefrançoıs, C., Fradın, J., Massıuu, F. E., \& Amalbertı, R. (2012). Cognitive-Adaptation Training for Improving Performance and Stress Management of Air Force Pilots. The International Journal of Aviation Psychology, 22(3), ss.203-223.

Gastil, J. (1994). A definition and 1llustration of democratic leadership. Journal of Human Relations, 47(8), ss.953-975.

Ginnett, R. C. (1993). Crews as groups: Their formation and their leadership. In E. Wiener, B. Kanki, \& R. Helmreich, Cockpit Resource Management (pp. ss.71-98). Orlando: FL: Academic Press.

Güney, S. (2015). Liderlik. İstanbul: Nobel yayıncilık. 
Examining of the Relationship Between Pilot's Leadership Styles and Crew Resource Management Practices (CRM) in Airline Operations

Gregorıch, S. E., Helmreich, R. L., \& Wilhelm, J. A. (1990). The Structure of Cockpit Management Attitudes. Journal of Apllied Psychology, 75(6), ss.682-690.

Helmreich, R., Merritt, A., Sherman, P., Gregorich, S., \& Wiener, E. (1993). The Flight Management Attitude Questionnaire. Texas, USA: NASA/UT/FAA Technical Report ss.93-94.

Helmreich, R., Wilhelm, J., \& Gregorich, S. (1988). Revised Versions of the Cockpit Management Attitudes Questionnaire (CMAQ) and CRM Seminar Evaluation Form. Texas, USA: NASA/UT Technical Report.

Hoogh, A. H., Greer, L. L., \& Hartog, D. N. (2015). Diabolical dictators or capable commanders? An investigation of the differential effects of autocratic leadership on team performance. The Leadership Quarterly, 26, ss.687-701.

Jony, M. T., Alam, M. J., Amin, M. R., \& Alam, M. J. (2019). The Impact of Autocratic, Democratic and Laissez-Faire Leadership Styles on the Success of the Organization: A Study on the Different Popular Restaurants of Mymensingh, Bangladesh. Canadian Journal of Business and Information Studies, 1(6), ss.28-38.

Karaman. H. (2018). Açımlayıcı Faktör Analizinde Kullanılan Faktör Çıkartma Yöntemlerinin Karşılaştırlması. Yüksek lisans Tezi, Hacettepe Üniversitesi, Eğitim Bilimleri Anabilim Dalı, Ankara.

Laukkala, T., Bor, R., Budowle, B., Navathe, P., Sajantıla, A., Sainio, M., \& Vuorio, A. (2018). Pilot Posttraumatic Stress Disorder and Fatal Aviation Accidents. Psychology and Applied Human Factors, 8(2), ss.93-99.

Loewenthal, K. M., Eysenck, M., Harrıs, D., Lubitsh, G., Gorton, T., \& Bicknell, H. (2000). Stress, distress and air traffic incidents: Job dysfunction and distress in airline pilots in relation to contextually assessed stress. Journal of Stress Medicine, 16, ss.179-183.

Luczak, A., \& Zużewıcz, K. (2006). Driver's tiredness and work safety. Indıa: Press Information Bureau. 2, ss.17-23

Maccoby, M. (1979). Leadership needs of the 1980's. Journal of Higher Education,

Maciejewska, M., \& Galant-Golebiewska, M. (2020). Assignation of Tiredness Indicator Based on the Pilot's Concentration and Speed Reaction Analysis During the Flight. Journal of Konbin, 50(3), ss.359-380.

Marshall, D. (2010). Crew Resource Management: From Patient Safety to High Reliability. Denver: CO: Safer Healthcare Partners.

Merritt, A. (1996). Ph.D. Dissertation. National Culture and Work Attitudes In Commercial Aviation: A Cross- Cultural Investigation. Texas, United States: The University of Texas at Austin.

Nanjundeswaraswamy, T., \& Swamy, D. R. (2014). Leadership Styles. Advances in Management, 7 (1), ss. 57-62. 
Examining of the Relationship Between Pilot's Leadership Styles and Crew Resource Management Practices (CRM) in Airline Operations

Ezgi Berte KUTLU- Mahmut Melih BAŞDEMİR

NTSB. (1978). Aircraft accident report: United Airlines, Inc. McDonnell-Douglas DC-8-81, N8082U Portland, Oregon. Washington: DC: United States Government.

Ojokuku, R. M., Odetayo, T., \& Sajuyigbe, A. (2012). Impact of Leadership Style on Organizational Performance: A Case Study of Nigerian Banks. American Journal of Business and Management, 1(4), ss.202-207.

Prince, C., Salas E., Brannick M., Prince A. (2010). The ifluence of experience and organizational goals on leadership in the military cockpit. The International Journal of Aviation psychology, 20(4), ss.375-389.

Sharma, J. K., \& Singh, S. K. (2013). Characteristics of Laissez-Faire Leadership Style: A Case Study. International Journal of Research in Commerce \& Management, 4(3), ss.29-31.

Tarsik, N. F., Kassim, N. A., \& Nasharudin, N. (2014). Transformational, Transactional or Laissez-Faire: What Styles do University Librarians Practice. Journal of Organizational Management Studies, 2014(2014), ss.1-10.

Yun, S., Faraj, S., \& Sims, H. P. (2007). Contingent leadership and effectiveness of trauma resuscitation teams. Journal of Applied Psychology, 90(6), ss.1288-1296.

Wang, Z., Liu, Y., Liu, S. (2019). Authoritarian leadership and task performance: the effects of leader-member exchange and dependence on leader. Journal of Frontiers of Business Research in China, 13(19), ss.1-15. 